
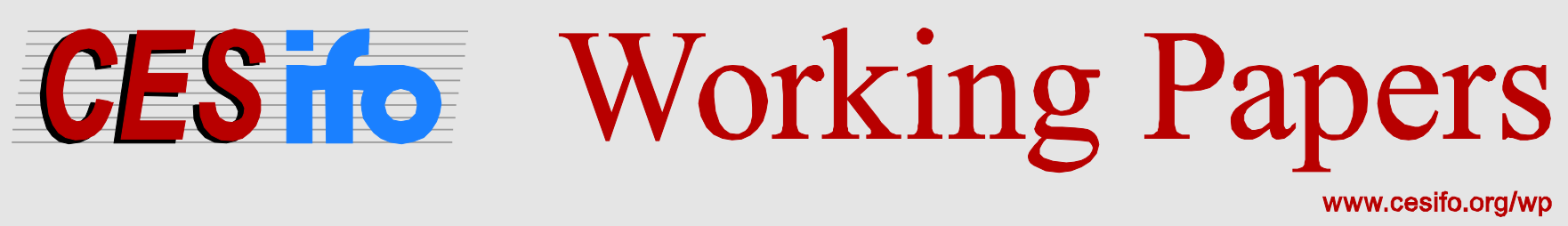

\title{
Just Hire your Spouse! Evidence from a Political Scandal in Bavaria
}

\author{
Björn Kauder \\ Niklas Potrafke
}

CESIFO WORKING PAPER NO. 4813

CATEgory 2: Public CHOICE

MAY 2014

An electronic version of the paper may be downloaded

- from the SSRN website:

- from the RePEc website:

- from the CESifo website:

WWW.SSRN.com

www.RePEc.org

www.CESifo-group.org/wp

\section{CESifo}




\title{
Just Hire your Spouse! Evidence from a Political Scandal in Bavaria
}

\begin{abstract}
We investigate a case of political favoritism. Some members of the Bavarian parliament hired relatives as office employees who were paid using taxpayers' money. We examine whether being involved in the scandal influenced re-election prospects and voter turnout. The results do not show that being involved in the scandal influenced the outcome and voter turnout of the 2013 state elections. We propose three explanations: (i) the Bavarian state election was a test run for the German federal election; (ii) the state government made a quite good job of clarifying failings; (iii) in June 2013, a very heavy bout of flooding eclipsed the political scandal.
\end{abstract}

JEL-Code: D720, H700, A130.

Keywords: political scandal, favoritism, nepotism, re-election prospects, voter turnout.

Björn Kauder

Ifo Institute - Leibniz Institute for

Economic Research at the University of Munich

Poschingerstrasse 5

Germany-81679 Munich

kauder@ifo.de
Niklas Potrafke

Ifo Institute - Leibniz Institute for

Economic Research

at the University of Munich

Poschingerstrasse 5

Germany-81679 Munich

potrafke@ifo.de

20 May 2014 


\section{Introduction}

Political scandals often have far-reaching consequences. Scandals influence, for example, politicians' election prospects. When an incumbent is discredited, a pertinent question is whether the incumbent will be re-elected. In a similar vein, challengers may not even have the chance of getting elected. Severe scandals bring individual political careers to an end. ${ }^{3}$

Political scandals have various facets: financial scandals include tax evasion, moral scandals include sexual misconduct. ${ }^{4}$ Prominent examples of sexual misconduct are President Bill Clinton’s affair with Monica Lewinsky and Dominique Strauss-Kahn’s sexual assault on a cleaning lady. In 1998, Bill Clinton did not resign as president of the United States, and because he was in his second term, he did not need to fear his re-election. By contrast, scandal brought Dominique Strauss-Kahn's political career to an abrupt end. Strauss-Kahn was the managing director of the International Monetary Fund and was expected to run as the presidential candidate of the French Socialists, who were seen as having the best chances of winning the 2011 French presidential elections.

When scandals occur, one issue is how politicians, especially party leaders or prime ministers, deal with the political scandals of their party or cabinet members (Dewan and Myatt 2007). When a minister involved in a scandal heeds the call to resign, a government's popularity may rise (Dewan and Dowding 2005). ${ }^{5}$

Scholars portray the consequences of political scandals. In the 1978-2008 United States' House elections, incumbents involved in scandals received 16 percentage points fewer votes in primary elections and 11 percentage points fewer votes in general elections as compared to non-scandal incumbents (Hirano and Snyder 2012). In Spanish local elections between 1996 and 2009, incumbents lost up to 14\% of votes when incumbents were accused

\footnotetext{
${ }^{3}$ In Japan, "the standard way of dealing with a scandal was to resign from the party and official posts but run again in the next elections” (Nyblade and Reed 2008: 930).

${ }^{4}$ Politicians either act corruptly for material gain or for electoral gain (Nyblade and Reed 2008).

${ }^{5}$ Doherty et al. (2011) examine scandalous behavior and the responsibilities of the official in question.
} 
with corruption and press coverage of such affairs was substantial (Costas-Pérez et al. 2012). ${ }^{6}$ Scandals involving the incumbent were also shown to have reduced trust in local politicians (Solé-Ollé and Sorribas-Navarro 2014). In Japan, candidates were shown to have lost 1.34\% of votes in the 1990 election because of scandals. In Great Britain, meanwhile, candidates were shown to have lost $1.14 \%$ of votes in the 1997 election due to scandals (Reed 1999). In the 2004 Brazilian municipal elections, the incumbents' re-election probability decreased by 7 percentage points when at least two cases of corruption were reported as compared to unaudited incumbents (Ferraz and Finan 2008). In the 2009 UK expenses scandal, press coverage reduced the vote shares of MPs involved in the scandal, but did not decrease the MPs’ probability of re-election. Voters were shown to have punished MPs and not the MPs' parties (Larcinese and Sircar 2012). Politicians were punished more by voters when voters expressed no clear preference for a specific party (Eggers 2014).

Political scandals are also likely to influence voter turnout. For example, when politicians are involved in political scandals, voters tend not to participate in elections due to their increased disenchantment with politics. Experts show, however, that corruption raises voter turnout. In the 1979-2005 United States' gubernatorial elections, corruption was shown to increase voter turnout (Escaleras et al. 2012). In the 1987 county supervisor elections in Mississippi, voter turnout was also shown to have been higher in corrupt counties (Karahan et al. 2006). Moreover, a 1988 ballot in Mississippi, provides another example of corruption increasing voter turnout (Karahan et al. 2009). ${ }^{7}$ When corruption rents were available in a jurisdiction, politicians were more likely to increase their campaigning efforts in order to capitalize on the benefits of holding office. Campaigning effort may well give rise to high voter turnout.

\footnotetext{
${ }^{6}$ Puglisi and Snyder (2011) examine how newspapers' ideology influences media coverage of scandals in the United States. Bowler and Karp (2004) discuss how scandals influence the regard for political institutions.

${ }^{7}$ On determinants of voter turnout, see, for example, Amaro de Matos and Barros (2004), Geys (2006), Martins and Veiga (2013), Schram and van Winden (1991), Smets and van Ham (2013), and Tao et al. (2011). On vote and popularity functions, see Lewis-Beck and Stegmaier (2013).
} 
In April 2013, Germany’s largest state Bavaria experienced a new political scandal of favoritism. Members of the Bavarian parliament (Landtag) had hired relatives as office employees who were paid by the Bavarian parliament (“nepotism”). The scandal became public because the expert in German parliamentary affairs Hans Herbert von Arnim published a book elaborating on how Bavarian politicians benefit from being in office (Arnim 2013). In 2000, the Bavarian parliament tightened the state law. Members of parliament were no longer allowed to hire spouses, children, or parents as office employees. ${ }^{8}$ An interim arrangement made it possible to employ relatives that had already assisted them prior to the tightening of the law. However, as long as 13 years after the interim arrangement was introduced, some MPs still employed close relatives. Employing these relatives did not break the law, but certainly smacked of exploiting taxpayers’ money. ${ }^{9}$

The state elections in Bavaria on 15 September 2013 and the German federal elections on 22 September 2013 attached a great deal of importance to this scandal. Politicians involved in the scandal realized the political hazard: some politicians who had hired relatives repaid the relatives’ salaries immediately or donated the amounts. Some MPs considered hiring relatives as legitimate in earlier times, but acknowledged that nowadays MPs should not hire relatives. Although three parties are involved in the scandal, it is conceivable that the reigning conservative Christian Social Union (CSU) incurred the largest loss of votes. About $70 \%$ of the involved politicians are CSU members. The opposition parties tried to exploit the scandal to increase their election prospects and replace the predominant CSU-led state government.

\footnotetext{
${ }^{8}$ The law still allowed for employing relatives other than spouses, children, and parents. In May 2013 the Bavarian parliament also decided to prohibit employing these relatives as of June 2013. In Italy, public sector employees have been shown to favor their children and support their access to public sector positions (Scoppa 2009). In the Philippines, relatives of elected MP candidates were more likely to take up office in the future than relatives of MP candidates that were not elected (Querubin 2013).

${ }^{9}$ Couch et al. (1992) describe how legislators in Alabama, who were at the same time employed in the public education system, influenced the allocation of public funds.
} 
The family scandal in Bavaria was a hot issue in the German media for many weeks. ${ }^{10}$ We examine how the scandal influenced the outcome and voter turnout of the 2013 state elections.

\section{Institutional background}

\subsection{The Bavarian political party landscape}

The conservative CSU has dominated politics in Bavaria for decades. ${ }^{11}$ The leftist Social Democratic Party (SPD) did not play an important role in Bavaria. All state prime ministers except one SPD prime minister between 1954 and 1957 - were members of the CSU.

The much smaller Free Democratic Party (FDP) formed a coalition with the CSU in the 2008-2013 legislative period. Before 2008 the CSU was in power without any coalition partner for 42 years. Figure 1 portrays the predominant role of the CSU in Bavarian state elections. The CSU only formed coalitions with partners such as the SPD and the FDP prior to 1966. The Greens (Bündnis 90/Die Grünen) have been represented in parliament since 1986 and the Free Voters (Freie Wähler) since 2008. The Greens never obtained more than $10 \%$ of the vote, while that achieved by the Free Voters barely exceeded $10 \%$.

\subsection{Bavarian state elections}

In Bavarian state elections voters cast two votes in a personalized proportional representation system. The first vote determines which candidate obtains the direct mandate in one of the 90 electoral districts with a bare majority. The second vote sorts politicians on their party lists. The first and second votes determine how many seats the individual parties receive in parliament. Each party that received at least 5\% of the first and second votes obtains a number

\footnotetext{
10 The media play a key role in (de)lighting political scandals. Ideologically biased media that favor the incumbent or challenger have incentives to hype or understate scandals.

${ }^{11}$ In other German states the conservatives are not represented by the CSU but by their sister party, the Christian Democratic Union (CDU). No party competition emerges between the CDU and the CSU and they form one faction in the federal parliament.
} 
of the 180 seats in the parliament according to the party's first and second vote share. Candidates voted into the parliament with the first vote (direct mandate) obtain their seats first. Candidates from party lists obtain the remaining seats. When the number of direct mandates exceeds the party's vote share in a region, the party obtains excess mandates, and the other parties obtain equalizing mandates.

\section{Empirical analysis}

\subsection{MPs hiring relatives}

The Bavarian president of parliament, Barbara Stamm, published a list including those MPs that employed spouses, children, or parents within the 2008-2013 legislative period and during the two preceding legislative periods (Stamm list, published on 3 May 2013). The list includes 79 (out of 360) MPs from the 2008-2013 legislative period and the two preceding legislative periods. ${ }^{12}$ Three politicians from this list have died in the meantime, 54 are members of the reigning Christian Social Union (CSU), 20 are members of the Social Democratic Party (SPD), one is a member of the Greens (Bündnis 90/Die Grünen), and one left the Greens to become an independent MP. MPs from the 2008-2013 coalition partner of the CSU, the Free Democratic Party (FDP), and MPs from the Free Voters (Freie Wähler) were not affected by the scandal. 17 politicians from the Stamm list were still MPs in the 2008-2013 legislative period (all CSU members); three of them were even ministers in the 2008-2013 government. The SPD and Green politicians from the Stamm list left the parliament by 2008 at the latest. 16 of the MPs involved in the scandal only hired relatives during the year 2000, shortly before the interim arrangement took effect. It is conceivable that these MPs hired relatives despite the fact that or because they knew that hiring relatives was going to be forbidden. To be sure, some MPs also hired relatives other than spouses, children,

\footnotetext{
${ }^{12}$ Note that only 205 out of 360 MPs were able to hire relatives according to the interim arrangement, because only 205 politicians were MPs before the interim arrangement took effect.
} 
or parents. Hiring relatives other than spouses, children, or parents did not violate the law. We, however, do not include relatives other than spouses, children, or parents because the MPs who hired them did not appear on the Stamm list; but these politicians were also criticized in the public debate.

Figure 2 shows the shares of the parties’ MPs that employed relatives. The share of CSU MPs that hired relatives (44\%) is higher than the share of SPD MPs that hired relatives (29\%). The share of the Green MPs that hired relatives is substantially smaller (8\%). The FDP and the Free Voters did not employ relatives. A t-test on means shows that there is a significant difference between CSU and SPD politicians in hiring relatives. We reject the hypothesis of no difference between CSU and SPD politicians with a t-value of 1.98.

\subsection{Vote shares and voter turnout}

The conservative CSU won the state elections on 15 September 2013 and received $48 \%$ of the total votes. As in the 2008 election, the CSU won all districts except one in the 2013 election. We examine how the scandal influenced the vote share of the CSU by comparing every individual district in the elections of 2008 and 2013. As the SPD and Green MPs who hired relatives left the parliament by 2008 at the latest, we consider no other party than the CSU when we examine how the scandal influenced the election outcome. We directly investigate how the scandal influenced a politician's re-election when the individual politician ran for office again after she/he experienced the scandal. ${ }^{13}$ In cases where the scandal brought a politician's career to an end, or a politician would have ended her/his career in any event - the scandal notwithstanding - we cannot compare the individual vote of the elections in 2008 and 2013. We thus also compare the vote share of the CSU in districts affected by the scandal

\footnotetext{
${ }^{13}$ In districts that were not adjusted between the 2008 and the 2013 state elections, 50\% of the MPs who hired relatives and $63 \%$ of the MPs who did not hire relatives stood for re-election. A t-test on means shows that there is no significant difference between MPs who hired relatives and MPs who did not hire relatives in the decision to stand for re-election. We do not reject the null hypothesis of no difference between MPs who hired relatives and MPs who did not hire relatives with a t-value of 0.94 .
} 
with the vote share of the CSU in districts not affected by the scandal, independent of the party's candidate. It is conceivable that the scandal also influenced voter turnout as a result of disenchantment with politics. We therefore examine how the scandal influenced voter turnout by comparing the elections of 2008 and 2013 in each individual district.

\subsection{Descriptive statistics}

We use data from the Centre of Bavarian History, the Bavarian Statistical Office, the Bavarian parliament, and MPs’ personal websites. We only include those (73 out of 91) districts that have not been adjusted between the 2008 and the 2013 state elections. Tables 1 and 2 show descriptive statistics. The samples include 88 and 146 observations.

Figure 3 shows polls for the 2008-2013 legislative period. The scandal emerged in April/May 2013 and, as Figure 3 shows, CSU vote intentions declined from about 49\% to about 46\% in April/May 2013. The CSU recovered slowly from the scandal. The CSU vote share was $47 \%$ and $48 \%$ in July and August 2013. Figure 4 shows the first vote share of the CSU in the state elections 2008 and 2013, for districts that were and were not affected by the scandal. The CSU first vote share increased from $45 \%$ to $49 \%$ in scandal districts and from $43 \%$ to $47 \%$ in other districts. A t-test on means shows that there is no significant difference between scandal districts and other districts in the CSU first vote share change. We do not reject the null hypothesis of no difference between scandal districts and other districts with a t-value of 0.44 . Figure 5 shows the total vote share (sum of first and second votes) of the CSU in the state elections 2008 and 2013, for districts being and not being affected by the scandal. The CSU total vote share increased from $47 \%$ to $50 \%$ in scandal districts and from $44 \%$ to $48 \%$ in other districts. A t-test on means shows that there is no significant difference between scandal districts and other districts in the CSU total vote share change. We do not reject the null hypothesis of no difference between scandal districts and other districts with a t-value of 1.57. Figure 6 shows the voter turnout in the state elections 2008 and 2013, for districts that 
were and were not affected by the scandal. The voter turnout increased from $58 \%$ to $63 \%$ in scandal districts and from $58 \%$ to $64 \%$ in other districts. A t-test on means shows that there is no significant difference between scandal districts and other districts in the voter turnout change. We do not reject the null hypothesis of no difference between scandal districts and other districts with a t-value of 0.00 .

\subsection{Empirical strategy}

The difference-in-differences model takes the following form:

$$
\begin{gathered}
\text { Voters' reaction }{ }_{i j t}=\alpha_{j}+\beta_{j} \text { Hired relative }_{i}+\gamma_{j} 2013_{i t}+\delta_{j} \text { Hired relative }_{i}{ }^{*} 2013_{i t} \\
+\sum_{k} \varepsilon_{j k} \text { Personal characteristics }_{i k t}+\zeta_{j} \text { Flood disaster }_{i t}+\eta_{j} \text { City }_{i}+\Sigma_{l} \theta_{j l} \text { Region }_{i l}+u_{i t} \\
\text { with } \mathrm{i}=1, \ldots, 73 ; \mathrm{j}=1, \ldots, 3 ; \mathrm{k}=1, \ldots, 4 ; \mathrm{l}=1, \ldots, 6 ; \mathrm{t}=1,2
\end{gathered}
$$

where Voters' reaction ${ }_{i j t}$ describes the CSU first or total vote share or the voter turnout in the

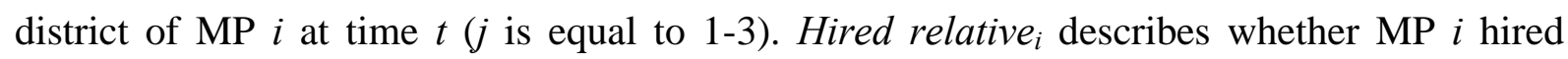
relatives and assumes the value one when the MP $i$ was on the Stamm list and zero otherwise. The dummy variable $2013_{i t}$ assumes the value one for the year 2013 . Hired relative ${ }_{i} * 2013_{i t}$ describes the interaction term, with $\delta$ describing the difference-in-differences estimate of the treatment effect. We include other control variables: Age $_{i t}$ describes the age of the MP at time $t$. The dummy variable Female $_{i}$ assumes the value one for female MPs. The dummy variable Incumbent running $_{i t}$ assumes the value one if the district incumbent ran again for MP. For explaining voter turnout, Vote margin $_{i t}$ describes how first vote shares differed between the district winner and the runner-up (see Nyblade and Reed 2008). In June 2013, exceptional rainfalls influenced a tremendous flooding. Natural disasters have been shown to influence reelection prospects (e.g. Bechtel and Hainmueller 2011). We therefore include the dummy 


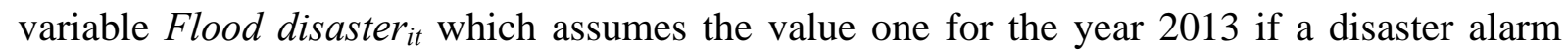
was given in a city or county of the electoral district of MP $i$ in the course of the 2013 flood in Central Europe. ${ }^{14}$ The dummy variable City $_{i}$ assumes the value one if an independent city was located in the electoral district. Region $i l$ describes a set of dummy variables for the regions where the individual MPs were elected (reference category: Oberbayern), and $u_{i t}$ describes an error term. We estimate a difference-in-differences model with standard errors robust to heteroskedasticity (Huber/White/sandwich standard errors - see Huber 1967 and White 1980).

\subsection{Regression results}

The results in Table 3 do not show that the scandal influenced the CSU vote share as measured by the 2013 and the 2008 state election results. The estimate in column (1) of Table 3 considers the CSU first vote results and thus only includes those MPs and MP candidates that were elected in 2008 (and re-elected in 2013) into parliament with the first vote. The results do not indicate that the scandal was associated with the CSU share of first votes: the interaction term between Hired relative $e_{i}$ and 2013 does not turn out to be statistically significant at conventional levels. The results also do not indicate a scandal district specific effect $\left(\right.$ Hired relative $_{i}$ ) or that the CSU first vote share was higher or lower in 2013. The age of the MP or MP candidate, whether the MP or MP candidate is female, and whether the MP or MP candidate is the incumbent do not turn out to be statistically significant. ${ }^{15}$ The CSU first vote share increased in cases where the district was affected by the 2013 flood disaster. The effect is statistically significant at the $1 \%$ level. The numerical meaning of the effect is that when the district was affected by the flood the CSU first vote share increased by 6.7

\footnotetext{
${ }^{14}$ We coded the flooding variable according to http://upload.wikimedia.org/wikipedia/commons/thumb/5/50/ Karte_Hochwasser_in_Deutschland_Landkreise.png/972px-Karte_Hochwasser_in_Deutschland_Landkreise.png ${ }^{15}$ To be sure, the incumbent variable assumes the value one for all MPs in the year 2013 because we include only MPs that have been elected in 2008 (and re-elected in 2013). The incumbent variable assumes, however, the value zero for the year 2008 when the MP candidate was not elected in the year 2003.
} 
percentage points. The magnitude of the effect resembles the 7 percentage points effect for the 2002 Elbe flooding (Bechtel and Hainmueller 2011). The CSU first vote share decreased when an electoral district included an independent city. The effect is statistically significant at the $1 \%$ level. The numerical meaning of the effect is that the CSU first vote share decreased by 4.6 percentage points in cases where an electoral district included an independent city. The electoral districts also influenced the CSU first vote share. The CSU first vote share was higher in Oberpfalz, Oberfranken, Unterfranken and Schwaben as compared to Oberbayern (reference category). The effects are statistically significant at the $1 \%$ level. The numerical meaning of the effects is that the CSU obtained 10.5 percentage points in Oberpfalz, 6.3 percentage points in Oberfranken, 5.2 percentage points in Unterfranken, and 3.9 percentage points more first votes in Schwaben as compared to Oberbayern. The CSU first vote share was also higher in Niederbayern. The effect is statistically significant at the $10 \%$ level. The numerical meaning of the effect is that the CSU obtained 3.3 percentage points more first votes in Niederbayern as compared to Oberbayern. The effect of Mittelfranken lacks statistical significance at conventional levels.

The estimate in column (2) of Table 3 considers the CSU total vote results and includes all electoral districts, including those where the MP candidate changed between 2008 and 2013. The results do not indicate that the scandal was associated with the CSU share of total votes: the interaction term between Hired relative and 2013 does not turn out to be statistically significant at conventional levels. The results also do not indicate a scandal district specific effect (Hired relative). The CSU total vote share was higher in 2013. The effect is statistically significant at the $1 \%$ level. The numerical meaning of the effect is that the CSU total vote share increased by 2.9 percentage points as compared to 2008 . The effects of the age and gender of the MP or MP candidate and whether she/he was the incumbent lack statistical significance. The CSU total vote share increased when the district was affected by the 2013 flood disaster. The effect is statistically significant at the $1 \%$ level. The numerical 
meaning of the effect is that when the district was affected by the flood the CSU total vote share increased by 5.9 percentage points. The CSU total vote share decreased when an electoral district included an independent city. The effect is statistically significant at the $1 \%$ level. The numerical meaning of the effect is that the CSU total vote share decreased by 5.2 percentage points when an electoral district included an independent city. The CSU total vote share also differed across regions: The CSU total vote share was highest in Oberpfalz, Unterfranken, and Schwaben. The effects are statistically significant at the $1 \%$ level. The numerical meaning of the effects is that the CSU obtained 7.5 percentage points in Oberpfalz, 6.0 percentage points in Unterfranken, and 4.9 percentage points more total votes in Schwaben as compared to Oberbayern (reference category). The CSU total vote share was also higher in Oberfranken and Niederbayern. The effects are statistically significant at the $5 \%$ and $10 \%$ level. The numerical meaning of the effects is that the CSU obtained 3.8 percentage points in Oberfranken and 2.3 percentage points more total votes in Niederbayern as compared to Oberbayern. The effect of Mittelfranken lacks statistical significance at conventional levels.

The estimate in column (1) of Table 4 considers voter turnout and includes all electoral districts. The results do not indicate that the scandal was associated with voter turnout: the interaction term between Hired relative and 2013 does not turn out to be statistically significant at conventional levels. The scandal district specific effect (Hired relative) does also not turn out to be statistically significant. The results do, however, indicate that voter turnout was higher in 2013. The effect is statistically significant at the $1 \%$ level. The numerical meaning of the effect is that voter turnout increased by 5.8 percentage points as compared to 2008. The effects of the age and gender of the MP or MP candidate, and whether the MP or MP candidate was the incumbent lack statistical significance. The effect of the vote margin between the winner and the runner-up of the district and the effect of the flood disaster also do not turn out to be statistically significant at conventional levels. Voter 
turnout decreased when an electoral district included an independent city. The effect is statistically significant at the $1 \%$ level. The numerical meaning of the effect is that voter turnout decreased by 3.2 percentage points when an electoral district included an independent city. Voter turnout differed across the electoral districts and was highest in Oberbayern (reference category); voter turnout was lower in Niederbayern, Schwaben, and Unterfranken. The effects are statistically significant at the $1 \%$ level. Voter turnout was 6.3 percentage points in Niederbayern, 5.0 percentage points in Schwaben, and 2.9 percentage points lower in Unterfranken as compared to Oberbayern. Voter turnout was also lower in Oberfranken. The effect is statistically significant at the $10 \%$ level. The numerical meaning of the effect is that voter turnout was 1.8 percentage points lower in Oberfranken as compared to Oberbayern. The effects of Oberpfalz and Mittelfranken do not turn out to be statistically significant.

\subsection{Robustness tests}

We tested whether the results change when we use the difference between the 2013 and the 2008 CSU first or total vote share or voter turnout as a dependent variable. Replicating Tables 3 and 4, the results do not show that the scandal influenced the change in the CSU first and total vote share and the voter turnout.

We tested whether the scandal influenced the CSU second vote share. Replicating column (2) of Table 3, the results do not show that the scandal influenced the CSU second vote share.

We tested whether the scandal influenced the other parties' vote shares. We replicated the regressions described in Table 3 with the vote shares of the SPD, the Greens, the FDP, and the Free Voters as a dependent variable. The results do not, however, indicate that other parties benefitted in districts where the CSU hired relatives. 
We tested how MPs who hired relatives during the year 2000 influenced the CSU vote share and voter turnout. We thus considered only those MPs who hired relatives during the year 2000 as being affected by the scandal. The results do not change as compared to considering all MPs who hired relatives as being affected by the scandal. We also tested whether the results are driven by including/excluding the MPs who hired relatives in the year 2000. Excluding the MPs who hired relatives in the year 2000, the results do not change as compared to including all MPs who hired relatives.

\section{Conclusion}

The family scandal in Bavaria 2013 was a hot issue in the German media for many weeks. The state elections in Bavaria on 15 September 2013 and the German federal elections on 22 September 2013 attached a great deal of importance to this scandal.

The results do not show that the scandal influenced the election outcome and voter turnout. So why did involvement in the scandal not influence re-election prospects and voter turnout? Three explanations spring to mind: firstly, the Bavarian state election on 15 September 2013 was a test run for the German federal election on 22 September 2013. State elections induce signaling effects for the federal elections. Given that the Bavarian electorate has more conservative views than the average German electorate, Bavarian voters wanted to give the CDU/CSU encouragement and prevent a left-wing federal government. Secondly, the conservative Bavarian government made a quite good job of dealing with the scandal and clarifying failings. The conservative faction leader immediately resigned; the conservative president of parliament compiled a list of all MPs involved in the scandal; and many MPs repaid the relatives' salaries. Thirdly, in June 2013, exceptional rainfalls influenced a huge amount of flooding. The state government again proved competent in its crisis management. This natural disaster eclipsed the political scandal at the time. 


\section{Acknowledgements}

We thank Hans Herbert von Arnim, Felix Arnold, Michael Bechtel, Rosemarie Fike, Benny Geys, James R. Hines Jr., Karsten Mause, William F. Shughart II, Albert Solé-Ollé, and participants of the 2014 meeting of the Public Choice Society, the 2014 meeting of the European Public Choice Society, the 2014 CESifo Area Conference on Public Sector Economics, and seminar participants in St. Gallen for helpful comments, and Lisa Giani Contini for proof-reading the paper. Danny Kurban, Benjamin Larin, and Jakob Müller provided excellent research assistance. 


\section{References}

Amaro de Matos, João and Pedro P. Barros (2004), Social norms and the paradox of elections' turnout, Public Choice 121, 239-255.

Arnim, Hans Herbert von (2013), Die Selbstbediener: Wie bayerische Politiker sich den Staat zur Beute machen, Heyne Verlag, München.

Bechtel, Michael M. and Jens Hainmueller (2011), How lasting is voter gratitude? An analysis of the short- and long-term electoral returns to beneficial policy, American Journal of Political Science 55, 851-867.

Bowler, Shaun and Jeffrey A. Karp (2004), Politicians, scandals, and trust in government, Political Behavior 26, 271-287.

Costas-Pérez, Elena, Albert Solé-Ollé and Pilar Sorribas-Navarro (2012), Corruption scandals, voter information, and accountability, European Journal of Political Economy 28, 469-484.

Couch, Jim F., Keith E. Atkinson and William F. Shughart II (1992), Ethics laws and the outside earnings of politicians: The case of Alabama’s “legislator-educators”, Public Choice 73, 135-145.

Dewan, Torun and Keith Dowding (2005), The corrective effect of ministerial resignations on government popularity, American Journal of Political Science 49, 46-56.

Dewan, Torun and David P. Myatt (2007), Scandal, protection, and recovery in the cabinet, American Political Science Review 101, 63-77.

Doherty, David, Conor M. Dowling and Michael G. Miller (2011), Are financial or moral scandals worse? It depends, Political Science \& Politics 44, 749-757.

Eggers, Andrew (2014), Partisanship and electoral accountability: Evidence from the UK expenses scandal, mimeo.

Escaleras, Monica, Peter T. Calcagno and William F. Shughart II (2012), Corruption and voter participation: Evidence from the US states, Public Finance Review 40, 789-815.

Ferraz, Claudio and Frederico Finan (2008), Exposing corrupt politicians: The effects of Brazil's publicly released audits on electoral outcomes, Quarterly Journal of Economics 123, 703-745.

Geys, Benny (2006), Explaining voter turnout: A review of aggregate-level research, Electoral Studies 25, 637-663.

Hirano, Shigeo and James M. Snyder Jr. (2012), What happens to incumbents in scandals? Quarterly Journal of Political Science 7, 447-456. 
Huber, Peter J. (1967), The behavior of maximum likelihood estimates under nonstandard conditions, Proceedings of the Fifth Berkeley Symposium on Mathematical Statistics and Probability, 221-233.

Karahan, Gökhan R., R. Morris Coats and William F. Shughart II (2006), Corrupt political jurisdictions and voter participation, Public Choice 126, 87-106.

Karahan, Gökhan R., R. Morris Coats and William F. Shughart II (2009), And the beat goes on: Further evidence on voting on the form of county governance in the midst of public corruption, Kyklos 62, 65-84.

Larcinese, Valentino and Indraneel Sircar (2012), Crime and punishment the British Way: Accountability channels following the MPs' expenses scandal, Political Science and Political Economy Working Paper 9, London School of Economics.

Lewis-Beck, Michael S. and Mary Stegmaier (2013), The VP-function revisited: A survey of the literature on vote and popularity functions after over 40 years, Public Choice 157, 367-385.

Martins, Rodrigo and Francisco J. Veiga (2013), Economic Performance and turnout at national and local elections, Public Choice 157, 429-448.

Nyblade, Benjamin and Steven R. Reed (2008), Who cheats? Who loots? Political competition and corruption in Japan, 1947-1993, American Journal of Political Science 52, 926-941.

Puglisi, Riccardo and James M. Snyder, Jr. (2011), Newspaper coverage of political scandals, Journal of Politics 73, 931-950.

Querubin, Pablo (2013), Family and politics: Dynastic incumbency advantage in the Philippines, mimeo.

Reed, Steven R. (1999), Punishing corruption: The response of the Japanese electorate to scandals, in O. Feldman, ed., Political psychology in Japan: Behind the nails that sometimes stick out (and get hammered down), Nova Science Publishers, Commack, New York, 131-148.

Schram, Arthur and Frans van Winden (1991), Why people vote: Free riding and the production and consumption of social pressure, Journal of Economic Psychology 12, 575-620.

Scoppa, Vincenzo (2009), Intergenerational transfers of public sector jobs: A shred of evidence on nepotism, Public Choice 141, 167-188.

Smets, Kaat and Carolien van Ham (2013), The embarrassment of riches? A meta-analysis of individual-level research on voter turnout, Electoral Studies 32, 344-359. 
Solé-Ollé, Albert and Pilar Sorribas-Navarro (2014), Do corruption scandals erode trust in government? Evidence from a matched sample of local governments, Paper presented at the CESifo Area Conference on Public Sector Economics 2014.

Tao, Ran, Fubing Su, Xin Sun and Xi Lu (2011), Political trust as rational belief: Evidence from Chinese village elections, Journal of Comparative Economics 39, 108-121.

White, Halbert (1980), A heteroskedasticity-consistent covariance matrix estimator and a direct test for heteroskedasticity, Econometrica 48, 817-838. 
Figure 1: The CSU is the predominant party in Bavaria

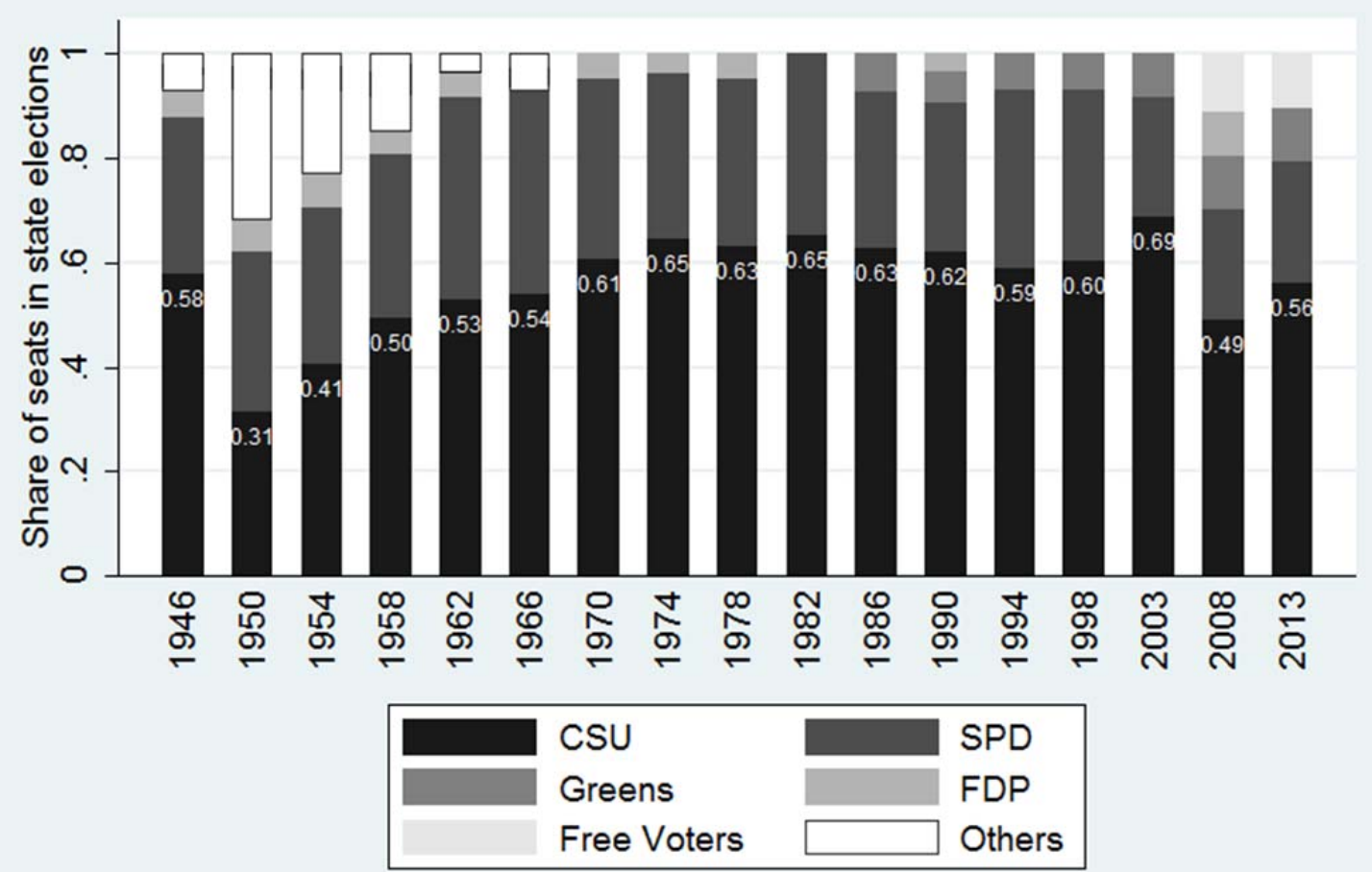

Source: Bavarian Statistical Office, own calculations

Figure 2: Only MPs from CSU, SPD, and Greens hired relatives

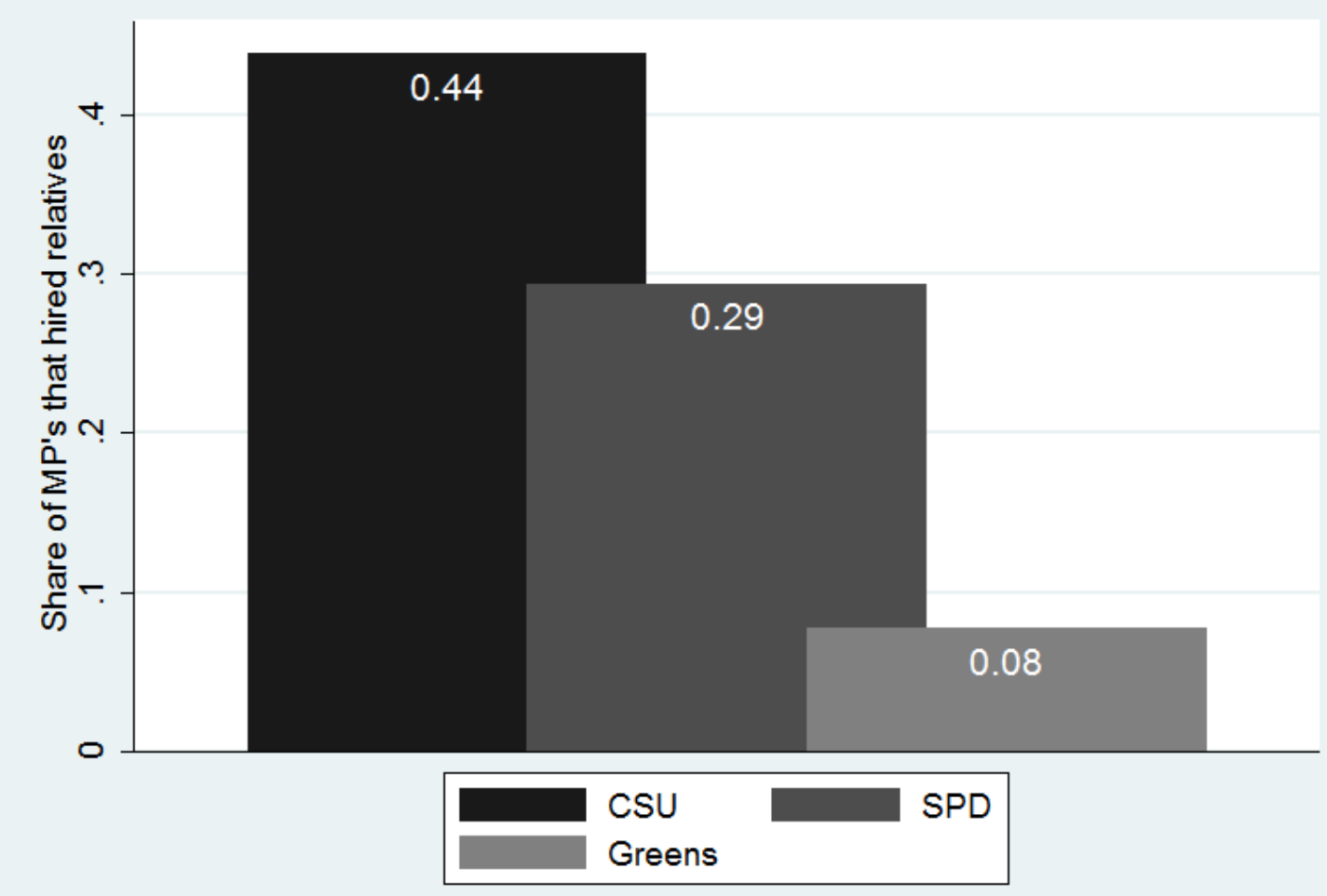

Source: own calculations

Number of MPs that hired relatives: CSU: 54, SPD: 20, Greens: 1.

T-test on means (difference between CSU and SPD) with t-value 1.98. 
Figure 3: The CSU lost in polls after the scandal emerged in April/May 2013

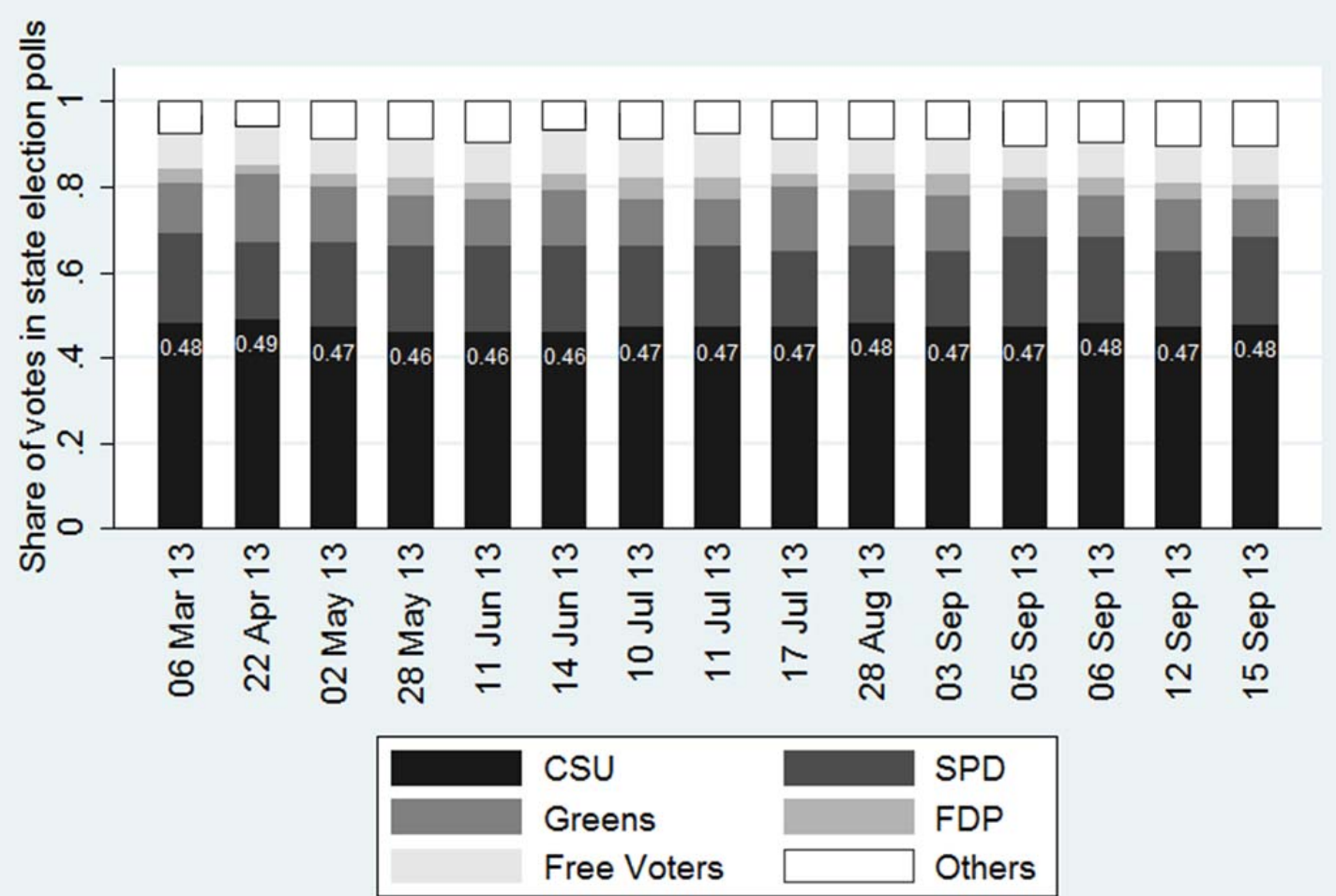

Source: www.wahlrecht.de

The last observation describes the 2013 state elections result.

Figure 4: The CSU obtained more first votes in both scandal and other districts

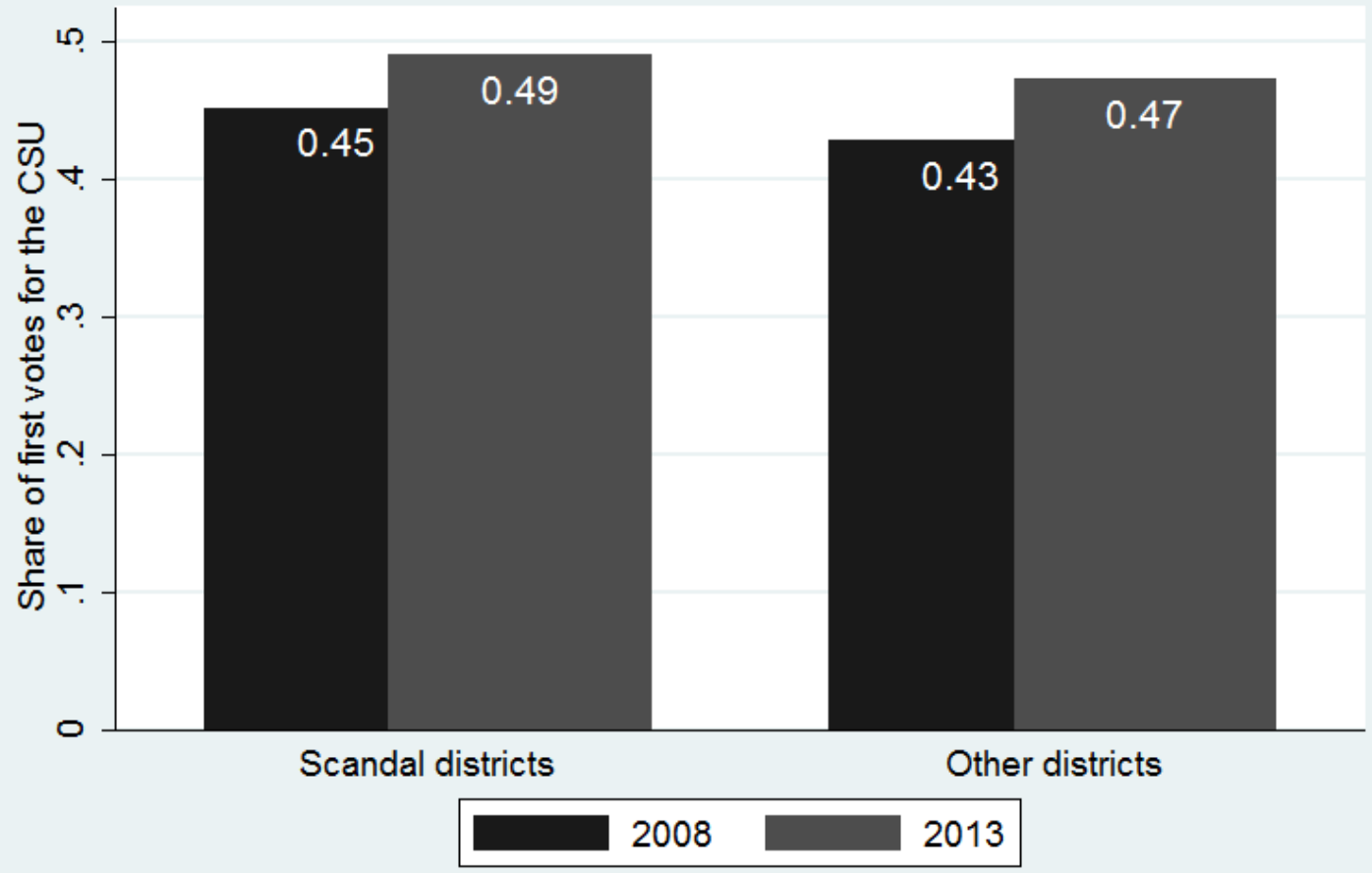

Source: Bavarian Statistical Office, own calculations

Number of scandal districts: 8, number of other districts: 36 .

T-test on means (difference between scandal districts and other districts) with t-value 0.44. 
Figure 5: The CSU obtained more total votes in both scandal and other districts

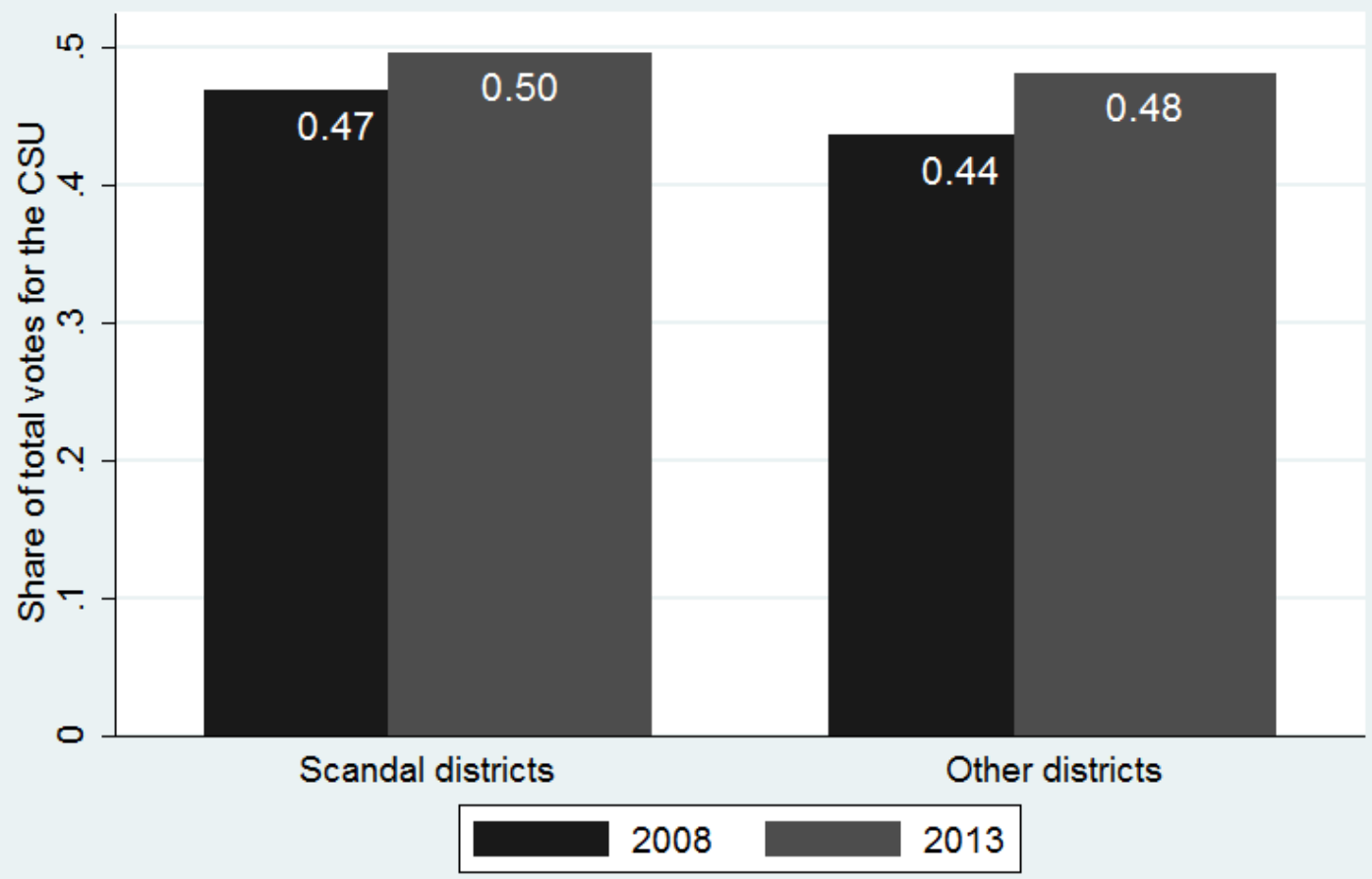

Source: Bavarian Statistical Office, own calculations

Number of scandal districts: 16, number of other districts: 57.

T-test on means (difference between scandal districts and other districts) with t-value 1.57.

Figure 6: Voter turnout increased in both scandal and other districts

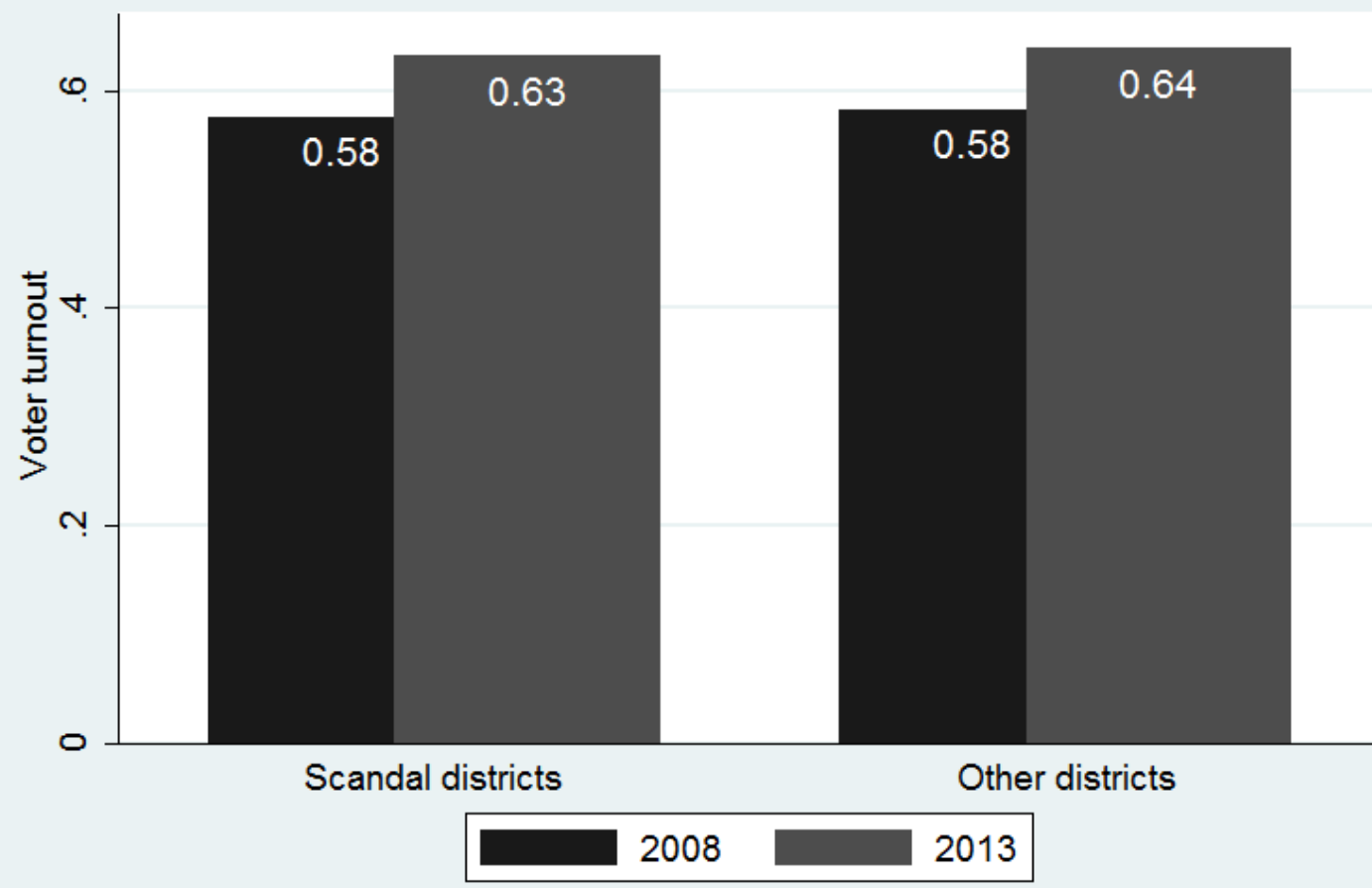

Source: Bavarian Statistical Office, own calculations

Number of scandal districts: 16, number of other districts: 57.

T-test on means (difference between scandal districts and other districts) with t-value 0.00 . 
Table 1: Descriptive statistics (sample excluding changed MP candidates)

\begin{tabular}{lrrrrr}
\hline & Obs. & Mean & Std. Dev. & \multicolumn{1}{c}{ Min } & \multicolumn{1}{c}{ Max } \\
\hline First vote share CSU 2008 & 44 & 0.43 & 0.05 & 0.30 & 0.54 \\
First vote share CSU 2013 & 44 & 0.48 & 0.06 & 0.34 & 0.63 \\
Hired relative & 88 & 0.18 & 0.39 & 0 & 1 \\
2013 & 88 & 0.50 & 0.50 & 0 & 1 \\
Age & 88 & 51.59 & 8.81 & 32 & 70 \\
Female & 88 & 0.14 & 0.35 & 0 & 1 \\
Incumbent running & 88 & 0.85 & 0.36 & 0 & 1 \\
Flood disaster & 88 & 0.13 & 0.33 & 0 & 1 \\
City & 88 & 0.43 & 0.50 & 0 & 1 \\
Niederbayern & 88 & 0.16 & 0.37 & 0 & 1 \\
Oberbayern & 88 & 0.32 & 0.47 & 0 & 1 \\
Oberpfalz & 88 & 0.02 & 0.15 & 0 & 1 \\
Oberfranken & 88 & 0.07 & 0.25 & 0 & 1 \\
Mittelfranken & 88 & 0.14 & 0.35 & 0 & 1 \\
Unterfranken & 88 & 0.11 & 0.32 & 0 & 1 \\
Schwaben & 88 & 0.18 & 0.39 & 0 & 1 \\
\hline
\end{tabular}

Table 2: Descriptive statistics (sample including changed MP candidates)

\begin{tabular}{lrrrrr}
\hline & Obs. & Mean & Std. Dev. & \multicolumn{1}{c}{ Min } & \multicolumn{1}{c}{ Max } \\
\hline Total vote share CSU 2008 & 73 & 0.44 & 0.05 & 0.30 & 0.54 \\
Total vote share CSU 2013 & 73 & 0.48 & 0.06 & 0.34 & 0.61 \\
Voter turnout 2008 & 73 & 0.58 & 0.04 & 0.49 & 0.66 \\
Voter turnout 2013 & 73 & 0.64 & 0.04 & 0.52 & 0.74 \\
Hired relative & 146 & 0.22 & 0.42 & 0 & 1 \\
2013 & 146 & 0.50 & 0.50 & 0 & 1 \\
Age & 146 & 51.00 & 9.11 & 31 & 70 \\
Female & 146 & 0.17 & 0.38 & 0 & 1 \\
Incumbent running & 146 & 0.69 & 0.46 & 0 & 1 \\
Vote margin & 146 & 0.26 & 0.10 & 0.03 & 0.52 \\
Flood disaster & 146 & 0.12 & 0.32 & 0 & 1 \\
City & 146 & 0.34 & 0.48 & 0 & 1 \\
Niederbayern & 146 & 0.12 & 0.33 & 0 & 1 \\
Oberbayern & 146 & 0.33 & 0.47 & 0 & 1 \\
Oberpfalz & 146 & 0.03 & 0.16 & 0 & 1 \\
Oberfranken & 146 & 0.07 & 0.25 & 0 & 1 \\
Mittelfranken & 146 & 0.16 & 0.37 & 0 & 1 \\
Unterfranken & 146 & 0.11 & 0.31 & 0 & 1 \\
Schwaben & 146 & 0.18 & 0.38 & 0 & 1 \\
\hline
\end{tabular}


Table 3: Regression results. Dependent variable: Vote share CSU. Difference in differences with standard errors robust to heteroskedasticity (Huber/White/sandwich standard errors)

(1) (2)

First vote Total vote

share CSU share CSU

\begin{tabular}{|c|c|c|}
\hline Hired relative*2013 & $\begin{array}{c}0.010 \\
(0.023)\end{array}$ & $\begin{array}{l}-0.003 \\
(0.017)\end{array}$ \\
\hline Hired relative & $\begin{array}{c}0.005 \\
(0.019)\end{array}$ & $\begin{array}{c}0.008 \\
(0.010)\end{array}$ \\
\hline 2013 & $\begin{array}{c}0.018 \\
(0.011)\end{array}$ & $\begin{array}{c}0.029 * * * \\
(0.008)\end{array}$ \\
\hline Age & $\begin{array}{c}0.000 \\
(0.001)\end{array}$ & $\begin{array}{l}-0.000 \\
(0.000)\end{array}$ \\
\hline Female & $\begin{array}{c}0.017 \\
(0.012)\end{array}$ & $\begin{array}{c}0.008 \\
(0.009)\end{array}$ \\
\hline Incumbent running & $\begin{array}{c}0.017 \\
(0.020)\end{array}$ & $\begin{array}{c}0.009 \\
(0.010)\end{array}$ \\
\hline Flood disaster & $\begin{array}{c}0.067 * * * \\
(0.024)\end{array}$ & $\begin{array}{c}0.059 * * * \\
(0.015)\end{array}$ \\
\hline City & $\begin{array}{c}-0.046 * * * \\
(0.011)\end{array}$ & $\begin{array}{c}-0.052 * * * \\
(0.008)\end{array}$ \\
\hline Niederbayern & $\begin{array}{l}0.033^{*} \\
(0.019)\end{array}$ & $\begin{array}{l}0.023^{*} \\
(0.013)\end{array}$ \\
\hline Oberpfalz & $\begin{array}{c}0.105 * * * \\
(0.021)\end{array}$ & $\begin{array}{c}0.075^{* * *} \\
(0.013)\end{array}$ \\
\hline Oberfranken & $\begin{array}{c}0.063 * * * \\
(0.015)\end{array}$ & $\begin{array}{c}0.038 * * \\
(0.016)\end{array}$ \\
\hline Mittelfranken & $\begin{array}{c}0.015 \\
(0.015)\end{array}$ & $\begin{array}{c}0.011 \\
(0.011)\end{array}$ \\
\hline Unterfranken & $\begin{array}{c}0.052 * * * \\
(0.014)\end{array}$ & $\begin{array}{c}0.060^{* * *} \\
(0.011)\end{array}$ \\
\hline Schwaben & $\begin{array}{c}0.039 * * * \\
(0.013)\end{array}$ & $\begin{array}{c}0.049 * * * \\
(0.011)\end{array}$ \\
\hline Constant & $\begin{array}{c}0.396 * * * \\
(0.040) \\
\end{array}$ & $\begin{array}{c}0.436^{* * *} \\
(0.025) \\
\end{array}$ \\
\hline $\begin{array}{l}\text { Observations } \\
\text { R-squared }\end{array}$ & $\begin{array}{c}88 \\
0.583\end{array}$ & $\begin{array}{c}146 \\
0.545\end{array}$ \\
\hline
\end{tabular}

Robust standard errors in parentheses; ${ }^{* * *} \mathrm{p}<0.01,{ }^{* *} \mathrm{p}<0.05,{ }^{*} \mathrm{p}<0.1$ 
Table 4: Regression results. Dependent variable: Voter turnout. Difference in differences with standard errors robust to heteroskedasticity (Huber/White/sandwich standard errors)

\begin{tabular}{lc}
\hline & $(1)$ \\
\hline Hired relative*2013 & -0.006 \\
Hired relative & $(0.013)$ \\
& 0.001 \\
2013 & $(0.010)$ \\
& $0.058^{* * *}$ \\
Age & $(0.007)$ \\
& 0.000 \\
Female & $(0.000)$ \\
& 0.006 \\
Incumbent running & $(0.009)$ \\
& -0.008 \\
Vote margin & $(0.008)$ \\
& 0.023 \\
Flood disaster & $(0.036)$ \\
& -0.012 \\
City & $(0.011)$ \\
Niederbayern & $-0.032^{* * *}$ \\
Oberpfalz & $(0.006)$ \\
& $-0.063^{* * *}$ \\
Oberfranken & $(0.011)$ \\
Mittelfranken & -0.027 \\
Unterfranken & $(0.018)$ \\
Schwaben & $-0.018^{*}$ \\
Constant & $(0.010)$ \\
R-squared & -0.011 \\
\hline dard errors in parentheses; $* * * \mathrm{p}<0.01, * * \mathrm{p}<0.05, * \mathrm{p}<0.1$ \\
\end{tabular}

